\title{
FUNCTIONAL AND PRAGMALINGUISTIC ASPECTS OF ENGLISH ADVERTISING TEXT OF TEA PRODUCTS
}

\section{Svitlana Nohovska ${ }^{1}$}

DOI: https://doi.org/10.30525/978-9934-26-050-6-58

The advertising message is a mean of presenting the information from the advertiser to the customer and it also has specific forms: textual, visual, audio, and symbolic. In order to make someone to read or listen to the advertisement there must be something special and interesting for the consumer. Moreover, in developing the advertisements there must be revealed the creative individuality of its creators.

The object of the study is a modern English advertising text of tea products.

The relevance of this research is determined by the need to process a functional paradigm for the study of verbal and non-verbal elements of modern English advertising texts.

\footnotetext{
${ }^{1}$ Borys Grinchenko Kyiv University, Ukraine
} 
The research aim is the thorough analysis of the application and implementation the communicative strategies in the advertising message via the use of both linguistic and non-linguistic tactics.

As for the reference corpus, it consists of 300 units of English advertising texts of tea products. The units have been obtained by the continuous selection from web-sites, social networks and English printed publications. The research material is saved in video, graphic and text formats.

To achieve the research aim we applied various forms of analysis, such as: functional, pragmalinguistic, morphological, lexical, syntactic, stylistic, quantative, and translational. Considering the scope of the article, we focused on the functional and pragmalinguistic approaches to the advertising messages that are included in the research corpus.

The functional analysis has been used to reveal the functional potential of the non-verbal components of communication. There are possible intersections between verbal and non-verbal communication, providing a dual encoding of information in the network of human consciousness through verbal units and non-verbal means.

Non-verbal components such as cinemas may be described through the following elements:

1. pictorial elements (illustrations, photos, and images): photo of the product; photo of the celebrity; photo of the product and the model; auxiliary background elements. The background images of Lipton Ice Tea include many elements, such as: falling tea leaves with lemon or lime, tea bottles on ice cubes, greenery, sunset by the ocean on a hot day, etc. Thus, Lipton Ice Tea is associated with nature, especially sunshine, coolness and naturalness. The Fuzetea logo has the illustration of a tea leaf, half of which includes the image of a fruit additive (e.g. lemon, peach, wild berries, etc.) that completes the perfect taste of a soft drink. The consumer associates the logo with nature, freshness and coolness. The graphic components of Ahmad Tea feature only the image of the traditional tea leaves and a teapot that is an integral part of the tea-drinking process.

2. fonts (regular, italic, bold, underline, combination of several types);

3. the method of order and placement of characters on the plane:
a. horizontal,
b. vertical,
c. increased spacing between the letters,
d. «inverted» words by $180^{\circ}$,
e. framing the text line of the figure or its element.

Encoding and decoding the content of the advertising message takes place by means of graphic symbols conveyed through specially selected fonts and their placement on the plane. Font is a graphic form of signs of a particular 
writing system in which letters are combined into words and words express thoughts [2, p. 277-278]. When it comes to advertising texts, exactly fonts help a word to become a visual-graphic symbol.

The choice of font and its placement depends on the purpose and idea of the advertisement. Perfectly-chosen font does not interfere with the perception of the advertising idea; on the contrary, it creates the mood and attitude of the recipient towards the advertised product. At the same time, the font as a visual sign system has cultural and philosophical implications [2, p. 277-278].

Dilmah Tea usually uses in advertising texts the handwriting font to emphasize the exclusivity of their product. They evoke a sense of confidence and provide great credibility. Capital letters are also used by Dilmah Tea to highlight the excerpts. The advertisers pay particular attention to characters order and placement on the plane. The lettering in Dilmah advertising messages is clear and visible from a distance (table 1). Thus, they ensure that the main advertising information will be seen and heard by the recipient:

Table 1

Combination of several fonts and placement of characters

\begin{tabular}{|l|l|}
\hline DILMAH CEYLON TEA & ANTIOXIDANTS \\
A Cup of Kindness & IN TEA \\
Made with Love & Can Protect Your Heart \\
\hline TEA INSPIRED RECIPE & ENJOY \\
Sip into Love with our & THE SUPER BOWL \\
ROSE WITH FRENCH & WITH A \\
VANILLA TEA SHAKE & SUPER \\
& BREW TEA \\
\hline
\end{tabular}

1. background colour. Advertising companies understand how the harmony of colour affects the consumer behaviour, thereby providing for people's reactions to their chosen colours. As the main colour scheme of Fuzetea is green and yellow it allows the consumer to compare iced tea with nature, freshness and coolness. The colour palette of Lipton Yellow Label Tea incorporates yellow as the main colour and red, white and green as additional colours. It provides the association of energy, vividness and sunny atmosphere that the consumer can get after a sip of tea. The corporate colours of Ahmad $\mathrm{Tea}$ are white and dark green that emphasize the closeness of the product to nature. They also evoke associations of purity, reliability and high quality of the tea.

Emotions, feelings, experiences are included in the communicative act in the form of various non-verbal means which are able to convey emotions, the attitude of subjects to each other and to the content of the conversation. In 
other words, the non-verbal means are entrusted with the function of manifestation of the psychological content of communication and the expression of emotional response [1, p. 210].

Pragmalinguistic analysis of advertising texts allows us to identify the main communicative strategies that can be regarded as a set of speech actions aimed at achieving the communicative goal. Communicative tactics is a hierarchically lower level of speech behaviour planning and acts as a mean to implement the strategy [2, p. 31]. The following strategies and tactics were recorded in the analyzed advertising texts of tea products:

- suggestion, which is represented by the tactics of using the imperative mood, duplication of letters, using a large number of simple sentences and repetition. The consumer persuasion is realized through a complex interaction of lexical, grammatical, stylistic and phonetic means. In the Brooke Bond advertisement is noticed the alliteration of letter [b]: Brooke Bond Choicest Blend. You won't find a better tea or Brooke Bond Scottish Blend. More flavor that our old bag. In advertising campaigns of tea products are often used the imperative mood. Brooke Bond: Spend wisely - save wisely. Lipton tea: Drink more - burn more. Lipton Ice Tea: Taste new Lipton Black Ice Tea Blueberry Taste. Thus, verbs of imperative mood are widely used for direct addressing to the customer.

- tactics of intimating communicative space (the use of pronouns you/your, emotionally valued words, abbreviated constructions and statements) and the discovery of solidarity with the addressee. Personal pronouns of different case forms are directly addressed to a particular individual and convey the meaning of a one-to-one, trusting and friendly relationship between the producer and the addressee. Lipton Tea: You can't buy happiness but you can You can buy tea and that's kind of the same thing. Lipton Tea: Love your heart. Lipton Ice Tea: Make your every moment at home a refreshing one. A refreshing experience no matter where you are.

- presentational strategy, embodied in the tactics of using personal and possessive pronouns we/our and negative presentation of competitors. Barry's Tea: We make the tea. You make the moment. Dilmah Tea: We hope you have a warm and comforting one today. Tea, a hug in a cup. Dilmah Tea: Try our tea infused gingerbread recipes! Tetley Tea: Our tea, our way. The negative presentation is used in Tetley Tea headline: Come to Britain, you're not in America.

- attention-grabbing strategy, implemented in the tactics of using the name of the advertised product, wordplay, the use of a striking headline/slogan, poetic form and non-verbal means. The pragmatic purpose of the advertisement is to use a catchphrase that emphasizes the main advantages of the advertised product and will be easy to remember. Lipton Chinese tea. 
Lipton tea can do that! Another good example is the usage of blending in advertised messages: Lipton Ice Tea, Join the LIPTON ICE TEAVOLUTION.

Advertising text is not only a statement of information or the promotion of certain products on the market but also it is a set of symbols transmitted from the advertiser to the consumer. It contributes the adequate understanding and memorization of the advertising information. Moreover, advertising messages have a communicative and pragmatic character; they intentionally act on the audience by imposing the advertised object. Thus, advertising emphasizes the concept of positioning brands.

\section{References:}

1. Botvinko O.M. (2011) Neverbalni zasoby na poznachennia prezyrstva $v$ anhlomovnomy dialohichnomu dyskursi [Nonverbal means to denote the contempt in English dialogic discourse]. Scientific Notes of Ostroh Academy National University: Philology Series, vol. 19, pp. 210-214.

2. Vladymyrska H.O., Vladymyrsky P.O. (2009) Reklama [Advertisement]: handbook. Kyiv: Kondor, p. 334.

3. Yemelyanova O.V. (2011) Variatyvnist comunicatyvnyh stratehiy ta taktyk dyskursu finansovoho prohnozu [The variability of communicative strategies and tactics of financial prediction discourse]. Journal of V.N. Karazin Kharkiv National University: Romano-Germanic Philology Series. Kharkiv, no. 953, pp. 30-34. 